\title{
Combined Corrosion Inhibitors and Mechanical Properties of Concrete Embedded Steel (AISI 316L) during Accelerated Saline Corrosion Test ${ }^{\dagger}$
}

\author{
Sofia Tsouli ${ }^{1}$, Angeliki G. Lekatou ${ }^{1,2}, * \mathbb{D}$, Spyridon Kleftakis ${ }^{1}$, Pantelis Gkoutzos ${ }^{1}$, Ilias K. Tragazikis ${ }^{3}$ \\ and Theodore E. Matikas ${ }^{3}$ D \\ 1 Laboratory of Applied Metallurgy, Department of Materials Science and Engineering, \\ School of Engineering, University of Ioannina, 45110 Ioannina, Greece; s.tsouli@uoi.gr (S.T.); \\ skleftak@uoi.gr (S.K.); gkoutzos.10gk@gmail.com (P.G.) \\ 2 Institute of Materials Science and Computing, University Research Center of Ioannina (URCI), \\ 45110 Ioannina, Greece \\ 3 Mechanics, Smart Sensors \& Nondestructive Evaluation Laboratory, Department of Materials \\ Science and Engineering, School of Engineering, University of Ioannina, 45110 Ioannina, Greece; \\ i.tragazik@uoi.gr (I.K.T.); matikas@otenet.gr (T.E.M.) \\ * Correspondence: alekatou@uoi.gr; Tel.: +30-26510-07309 \\ + Presented at International Conference on Raw Materials and Circular Economy, Athens, Greece, \\ 5-9 September 2021.
}

check for updates

Citation: Tsouli, S.; Lekatou, A.G.; Kleftakis, S.; Gkoutzos, P.; Tragazikis, I.K.; Matikas, T.E. Combined Corrosion Inhibitors and Mechanical Properties of Concrete Embedded Steel (AISI 316L) during Accelerated Saline Corrosion Test. Mater. Proc. 2021, 5, 72. https://doi.org/ 10.3390/materproc2021005072

Academic Editor: Evangelos Tzamos

Published: 10 December 2021

Publisher's Note: MDPI stays neutral with regard to jurisdictional claims in published maps and institutional affiliations.

Copyright: (c) 2021 by the authors. Licensee MDPI, Basel, Switzerland. This article is an open access article distributed under the terms and conditions of the Creative Commons Attribution (CC BY) license (https:// creativecommons.org/licenses/by/ $4.0 /)$.

\begin{abstract}
The objective of this effort is to study the effect that the combination of fly ash (FA) with a liquid corrosion inhibitor has on the mechanical degradation of 316L rebars embedded in concrete specimens during salt fog testing for a period of four months, as well as the porosity of concrete. Partial replacement of Ordinary Portland Cement (OPC) by FA (0-25\%) did not significantly affect the tensile properties of 316L except a small decrease in the elastic modulus and \% elongation with FA increasing. Both FA and FA-liquid inhibitor combination resulted in significant reductions in the porosity of the reinforced concrete after $4 \mathrm{~m}$ of salt fog testing.
\end{abstract}

Keywords: 316L rebars; fly ash; liquid diffuse inhibitor; salt fog; tensile properties; concrete porosity

\section{Introduction}

Reinforced concrete has been the most predominant construction material worldwide throughout the last two centuries due to its low price, high compressive strength, durability, and long service life [1-3]. The development of a passive oxide film on the surface of the steel reinforcement, as a consequence of the strongly alkaline environment $(\mathrm{pH} \approx 12.5-13.5)$ of concrete, delays/inhibits the initiation of steel corrosion due to the infiltration of aggressive species, such as $\mathrm{Cl}^{-}, \mathrm{CO}_{2}$, acids, etc., in the concrete through porosity or reactions [2-5].

Since many monuments and historical buildings are nearby/in sea-coastal and innercity regions, the corrosion of steel reinforcement due to environmental pollution leads to a rapid degradation of the reinforced concrete structure in terms of durability, bond strength and ability to withstand seismic activities [1-6]. This is mainly attributed to: (a) $\mathrm{Cl}^{-}$attack via concrete porosity leading to localized corrosion of steel [3-5], (b) concrete carbonation causing depassivation [3-5] or (c) acid attack [2]. Corrosion affects the bond strength between steel reinforcement and concrete since the formation of voluminous corrosion products in the concrete pores results in the development of internal stresses and consequent cracking/spalling of the concrete around the rebars. Simultaneously, the loss in the rebar cross-sectional area leads to loss of ductility, which in combination with local acidification at the steel/concrete interface causes marked deterioration of the rebar mechanical properties $[5,6]$. 
The utilization of AISI 316L stainless steel reinforcement in the supporting structure of monuments and historical buildings under restoration, for instance the ancient theater of Dodona in Greece, has been adopted in recent decades because of its superb corrosion resistance caused by the chromia protective surface layer, the molybdenum-due resistance to saline media, the nickel-owing stability of the passive layer, as well as its excellent mechanical properties $[7,8]$.

The replacement (to a certain extent) of cement with industrial byproducts, such as fly ash (FA), has been a reliable, economic, and environmentally-friendly method towards limiting corrosion of the reinforcing steel [3,9-11]. Fly ash powder is the pozzolanic secondary product of pulverized coal combustion in the thermoelectric power industry $[9,11]$. Addition of fly ash to the concrete mixture leads to the generation of C-S-H (calcium-silicatehydrate) by the pozzolanic reaction of the reactive silica contained in fly ash with the C-H $\left.\left(\mathrm{Ca}(\mathrm{OH})_{2}\right)\right)$ contained in the hydrated cement. C-S-H, a corrosion-resistant compound with binding abilities, not only consumes $\mathrm{C}-\mathrm{H}$ (that is susceptible to aggressive substances penetration) but also fills the voids and pores of the concrete [3,9-11]. Additionally, FA can lead to refinement of the concrete pore structure by reducing the pore volume as well as the critical pore size of concrete [3,9-11]. Moreover, other hydration products, like Friedel's salt, can fill voids and pores of the concrete structure, thereby decreasing its permeability [3,9-11].

Previous efforts have studied the electrochemical performance of stainless steels in electrolytes consisting of $\mathrm{Ca}(\mathrm{OH})_{2}$ and sodium chloride [12] or acid rain solutions [13-16]. The favorable effect of fly ash (maximized at 20\% replacement of $\mathrm{Ca}(\mathrm{OH})_{2}$ ) has been manifested [13-16]. The present study is a preliminary study aiming at evaluating the effect of FA combined with a liquid corrosion inhibitor (Inhibitor B) on the mechanical deterioration of bars reinforcing cubes of concrete after salt fog testing for a period of four months. Although industrial by-products are usually avoided in the framework of restoration of historical monuments, the addition of fly ash to cement could be a satisfactory alternative solution, as FA is an ecological material, which does not affect the appearance of concrete and additionally leads to the reduction of its permeability through the formation of products, such as Friedel's salt [3,9-11]. The incentive for this investigation is the limited number of works on the structural integrity of stainless steel reinforcement in marine environments as far as the restoration of architectural monuments is concerned.

\section{Materials and Methods}

316L austenitic stainless steel rebars (diameter: $6 \mathrm{~mm}$, length: $12 \mathrm{~mm}$ ) were employed. Portland Cement CEM II 42.5R was blended with class C-fly ash (ASTM C618-19) from the lignite mines of the Public Power Corporation of Greece, consisting of oxides of $\mathrm{Ca}, \mathrm{Si}, \mathrm{Al}$, $\mathrm{S}, \mathrm{Fe}$, and $\mathrm{Mg}$ (decreasing order of concentration) [13]. Inhibitor B, a liquid diffuse organic multifunctional corrosion inhibitor based on the complex compound of alkanolamine, which protects the reinforcement through the anodic/cathodic reaction, was applied on the concrete surface.

Concrete cubes $\left((7 \times 7 \times 7) \mathrm{cm}^{3}\right)$ composed of cement, CEN Standard sand and water (ratio: 1/3/0.5 according to BS EN 196-1-2005) and FA (replacing 0-25\% of cement), reinforced with 316L rebars and externally brushed with Inhibitor B underwent salt fog (spray) testing for a period of 4 months (Vötch cabinet, $5 \% \mathrm{NaCl}, 35^{\circ} \mathrm{C}$ ). Uniaxial tensile tests of the steel bars (after carefully removing the concrete cover) were carried out prior to and after 4 months of salt fog testing ( 5 replicate tests to extract a mean value) (Galdabini tester, cross-head speed: $1.30 \mathrm{~mm} / \mathrm{min}$, ASTM E8/E8M-09). The elastic moduli of the rebars, prior to and following salt spraying of the concrete cover, were measured by the Pulseecho ultrasonic method) [17]. Polished cross-sections of rebars (at ribs) prior to and after salt fog testing were inspected at the JeoL JSM 6510 LV Scanning Electron Microscope. The porosity of the concrete cubes before and after salt fog test was also measured (ASTM C 642-97). 


\section{Results and Discussion}

\subsection{Salt Fog Test and Mechanical Behavior}

Figure 1 illustrates the state (on visual examination) of two concrete cubes reinforced with 316L rebars containing 20\% fly ash (a \& b) and 20\% fly ash + Inhibitor B (c \& d) following exposure into the salt fog cabinet for a period of four months. A very satisfactory surface state is manifested for both specimens. Figure 2 demonstrates the stress vs. strain curves of $316 \mathrm{~L}$ bars after removal from the concrete cube ( 0 to $25 \%$ FA in cement, combined with Inhibitor B) before and after four months of salt fog testing. Table 1 lists the tensile values extracted from the curves, as well as the Young modulus values. Salt spraying for 4 months led to small decreases in the mechanical properties of the 316L rebar with FA increasing, which are statistically significant only in the cases of elastic modulus and elongation (\%).
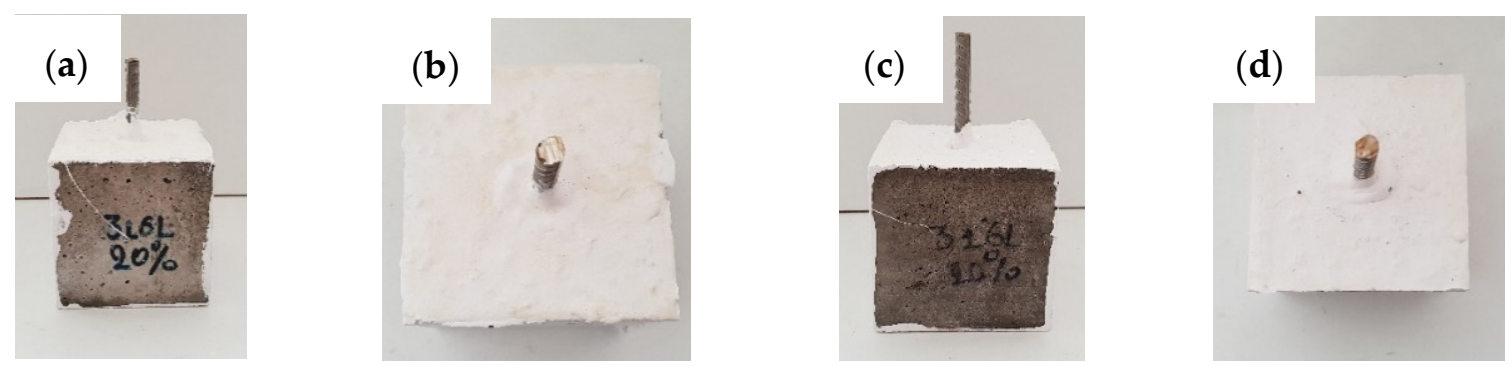

Figure 1. Concrete cubes reinforced by 316L having undergone salt fog test for 4 months: (a,b): $20 \%$ fly ash; (c,d) $20 \%$ fly ash + Inhibitor B.

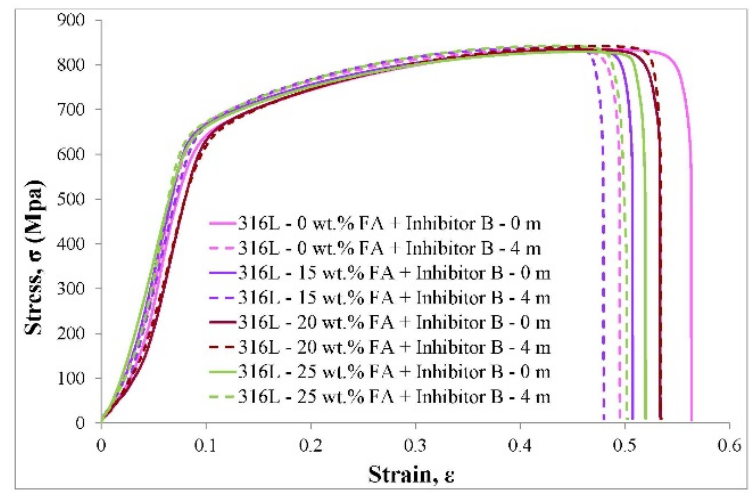

Figure 2. Tensile testing behavior of $316 \mathrm{~L}$ bars reinforcing concrete that contains fly ash $(0,15,20$, $25 \%$ of cement) in combination with Inhibitor B prior to $(0 \mathrm{~m})$ and after salt fog testing $(4 \mathrm{~m})$.

Table 1. Mechanical properties of $316 \mathrm{~L}$ bars reinforcing concrete that contains fly ash $(0,15,20,25 \%$ of cement) in combination with Inhibitor B prior to and after salt fog testing.

\begin{tabular}{ccccccc}
\hline $\begin{array}{c}\text { Fly Ash, } \\
\text { wt.\% }\end{array}$ & $\begin{array}{c}\text { Duration, } \\
\mathbf{m}\end{array}$ & $\begin{array}{c}\text { Elastic } \\
\text { Modulus, } \\
\text { GPa }\end{array}$ & $\begin{array}{c}\mathbf{0 . 2 \%} \text { Yield } \\
\text { Strength, } \\
\mathbf{M P a}\end{array}$ & $\begin{array}{c}\text { Tensile } \\
\text { Strength, } \\
\mathbf{M P a}\end{array}$ & $\begin{array}{c}\text { Fracture } \\
\text { Strength, } \\
\mathbf{M P a}\end{array}$ & \% EL \\
\hline 0 & 0 & $202 \pm 1$ & $553 \pm 19$ & $720 \pm 19$ & $688 \pm 24$ & $41 \pm 2$ \\
& 4 & $192 \pm 1$ & $539 \pm 51$ & $686 \pm 59$ & $657 \pm 56$ & $36 \pm 2$ \\
\hline 15 & 0 & $199 \pm 1$ & $550 \pm 20$ & $708 \pm 22$ & $675 \pm 27$ & $39 \pm 1$ \\
& 4 & $196 \pm 1$ & $544 \pm 23$ & $684 \pm 31$ & $639 \pm 22$ & $35 \pm 2$ \\
\hline 20 & 0 & $199 \pm 1$ & $541 \pm 17$ & $701 \pm 23$ & $652 \pm 27$ & $40 \pm 1$ \\
& 4 & $193 \pm 1$ & $540 \pm 27$ & $689 \pm 27$ & $645 \pm 27$ & $39 \pm 2$ \\
\hline 25 & 0 & $200 \pm 1$ & $535 \pm 40$ & $686 \pm 39$ & $641 \pm 42$ & $39 \pm 1$ \\
& 4 & $191 \pm 1$ & $507 \pm 34$ & $661 \pm 31$ & $615 \pm 35$ & $38 \pm 2$ \\
\hline
\end{tabular}


Table 2 presents the reduction percentage (\%) of mechanical property values after the salt fog test for concrete cubes embedded with 316L rebars and mixed with FA and FA + Inhibitor B. In general, FA addition led to smaller losses of mechanical properties compared to concrete cubes free of FA. A total of $20 \%$ FA addition led to the lowest losses in the mechanical properties (with the exception of the elastic modulus) in agreement with previous efforts that showed that $20 \%$ FA addition leads to the highest corrosion resistance for 316L and 304L rebars in electrolytes simulating concrete pores exposed to various harsh environments [13-16]. A total of $25 \%$ FA addition led to higher property losses compared to $20 \%$ FA, with analogy to electrochemical behavior tests [13-16].

Table 2. Decrease percentage (\%) of mechanical property values of 316L bars reinforcing concrete that contains fly ash $(0,15,20,25 \%$ of cement) in combination with Inhibitor B after salt fog spray testing.

\begin{tabular}{cccccc}
\hline $\begin{array}{c}\text { Fly Ash, } \\
\text { wt.\% }\end{array}$ & $\begin{array}{c}\text { Elastic } \\
\text { Modulus, } \\
\text { \% }\end{array}$ & $\begin{array}{c}\mathbf{0 . 2 \%} \text { Yield } \\
\text { Strength, } \\
\mathbf{\%}\end{array}$ & $\begin{array}{c}\text { Tensile } \\
\text { Strength, } \\
\mathbf{\%}\end{array}$ & $\begin{array}{c}\text { Fracture } \\
\text { Strength, } \\
\mathbf{\%}\end{array}$ & $\begin{array}{c}\text { \% } \\
\text { Elongation, } \\
\mathbf{\%}\end{array}$ \\
\hline 0 & 4.95 & 2.53 & 4.72 & 4.51 & 12.20 \\
15 & 1.51 & 1.09 & 3.39 & 5.33 & 10.26 \\
20 & 3.02 & 0.18 & 1.71 & 1.07 & 2.50 \\
25 & 4.50 & 5.23 & 3.64 & 4.06 & 2.56 \\
\hline
\end{tabular}

\subsection{Microstructure of Corroded 316L Embedded Rebars}

Figure 3 illustrates cross-sectional micrographs of 316L rebars removed from concrete cubes with fly ash $(0,20$, and $25 \%$ in cement) and Inhibitor B having undergone salt fog test for a period of four months at low magnifications. A fine surface state is demonstrated. High magnifications are displayed in Figure 4.
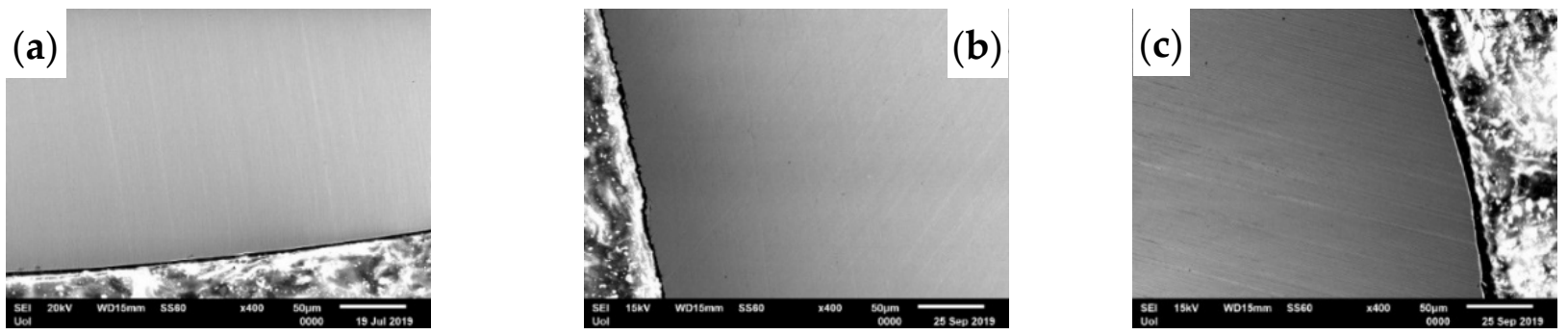

Figure 3. SEM images (cross-sections) of 316L rebars removed from concrete with Inhibitor B and (a) 0\% FA, (b) 20\% FA, and (c) $25 \%$ FA, after a salt fog test for a period of 4 months.
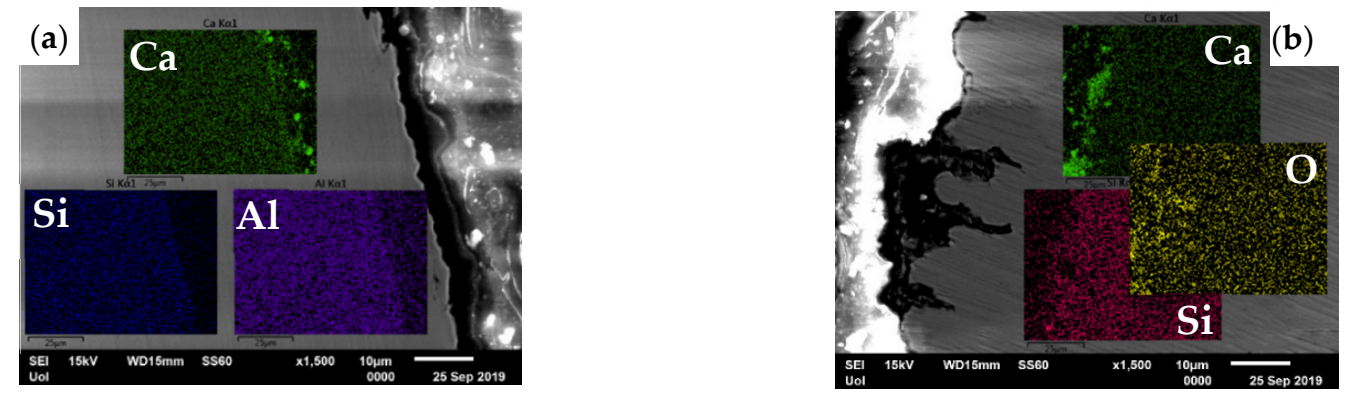

Figure 4. SEM images (cross-sections) of 316L rebars removed from concrete with Inhibitor B and (a) 20\% FA, (b) 25\% FA after a salt fog test for a period of 4 months; inset EDX elemental mapping.

The increased presence of $\mathrm{Ca}, \mathrm{O}, \mathrm{Si}$ and $\mathrm{Al}$ on the steel surface manifests the generation of a Ca-based oxide layer on 316L (Figure 4). Previous works on 316L polarized in simulating concrete pores solutions containing FA have claimed that FA participates in this film through its interaction with $\mathrm{Ca}(\mathrm{OH})_{2}$ [13-16]. The oxide layer is uniform in the case 
of $20 \%$ FA (Figure $4 a$ ). On the other hand, Figure $4 \mathrm{~b}$ illustrates the formation of pits on the surface of the rebar set in the concrete that includes $25 \%$ FA. It has been shown that high amounts of FA form agglomerates, which do not interact in a pozzolanic way with $\mathrm{Ca}(\mathrm{OH})_{2}$ owing to their coarse particle size [13-16]. Therefore, a uniform C-S-H film cannot be formed on the metallic surface. Instead, thick layers of poorly reacted agglomerates of FA have locally been deposited on steel, causing formation of differential aeration cells below them.

\subsection{Porosity of Concrete}

Figure $5 a, b$ illustrates the effect of FA in combination with Inhibitor B on the porosity of concrete prior to and following salt fog testing for a period of four months, respectively. Prior to salt spraying, the $0 \%$ FA cube presented the smallest porosity, while the $25 \%$ FA cube showed the largest. This can be explained by three reasons: (a) partially replacing cement with fly ash leads to higher total porosity due to greater water-to-cement ratio and smaller gel-to-space ratio [10]; (b) coarse particles of FA (i.e., agglomerates at high additions) increase the porosity of concrete as FA content increases owing to their relatively small specific surface area [18]; (c) the content of C-H decreases with increasing FA content and, therefore, less $\mathrm{C}-\mathrm{H}$ is available to react in a pozzolanic way with FA resulting in a decrease in the pozzolanic reaction rate of FA and an increase in porosity [19]. A similar trend is followed in the case of Inhibitor B, for the $15-25 \%$ FA. Inhibitor B leads to small reductions in porosity for $0 \%$ and $15 \%$ FA contents. At higher FA contents, the combination of FA and Inhibitor B has no statistically significant effect on the porosity of concrete compared to the sole addition of FA.
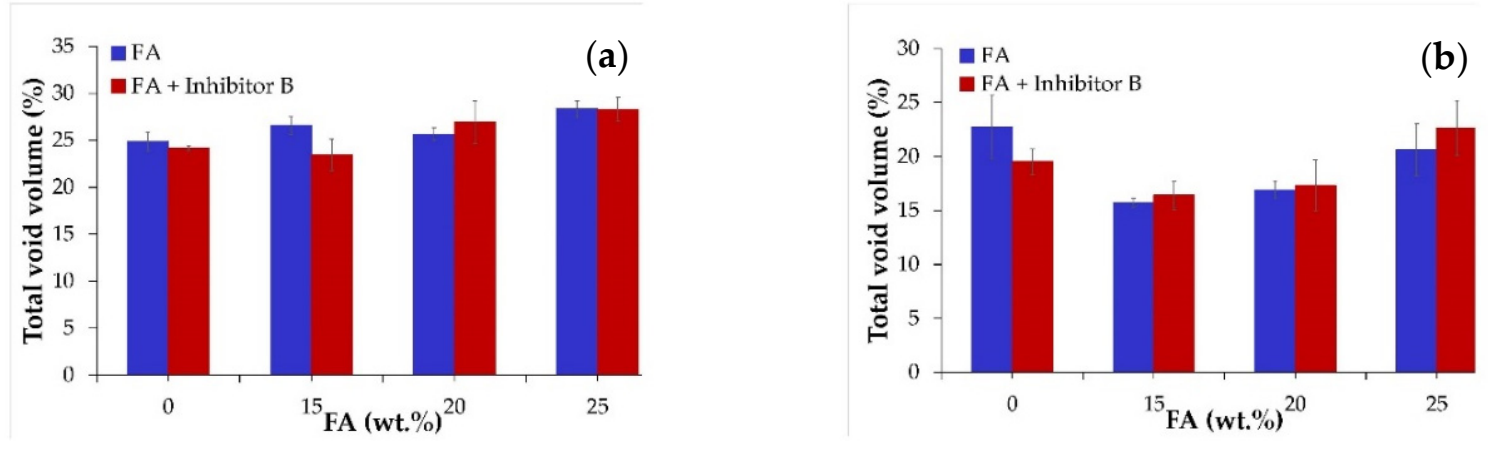

Figure 5. Effect of FA in combination with Inhibitor B on the porosity of concrete; (a) prior to and (b) after salt fog testing for a period of 4 months.

On the contrary, the fly ash addition has led to significant decreases in the porosity of the concrete cubes that have undergone salt fog test for four months as compared to the as-prepared cubes (Figure 5b). This is mainly explained by: (a) the production of more cement hydration compounds and the simultaneous refinement of porosity due to the cementitious/pozzolanic reactions that take place during the salt fog test [9-11,19]; (b) the excess $\mathrm{CaO}$ in FA reacts quickly with water and produces $\mathrm{Ca}(\mathrm{OH})_{2}$ in double volume [20]; (c) As the curing time increases with salt spraying, ettringite may be formed and transformed to other hydration compounds, thereby notably contributing to the reduction of the porosity [9,10]; (d) at the same time, as curing age increases, FA reduces the "critical pore size" resulting in reduced porosity compared to the FA-free concrete [10]. Combination of FA with Inhibitor B slightly increases the porosity of concrete compared to the sole employment of FA, within statistical error though.

\section{Conclusions}

- Salt fog testing for four months led to small decreases in the mechanical properties of 316L rebars set in concrete cubes containing FA + Inhibitor B with FA increasing. 
These decreases present statistical significance only in the cases of \% elongation and elastic modulus.

- Fly ash addition led to smaller losses of tensile properties compared to concrete cubes free of FA. Cement replacement by $20 \%$ FA led to the lowest losses in the tensile properties.

- On visual examination, the concrete cubes reinforced with 316L rebars remained intact of corrosion indications during a salt fog test for a period of four months.

- Microstructural examination of 316L embedded in concrete cubes after $4 \mathrm{~m}$ of salt fog testing revealed scarce pitting at the ribs at $25 \%$ FA.

- Partial replacement of OPC with FA led to an increase in porosity for both cases (FA-concrete and FA + Inhibitor B-concrete) before salt fog testing.

- After four months of salt fog testing, the addition of FA led to a significant decrease in porosity with $15 \%$ and $25 \%$ FA presenting the maximum reduction for both cases (FA-concrete and FA + Inhibitor B-concrete).

Institutional Review Board Statement: Not applicable.

Informed Consent Statement: Not applicable.

Data Availability Statement: Data sharing is not applicable to this article.

Acknowledgments: Our gratitude to SINTECNO Hellas for the provision of Inhibitor B.

\section{References}

1. Reichenbach, S.; Preinstorfer, P.; Hammerl, M.; Kromoser, B. A review on embedded fibre-reinforced polymer reinforcement in structural concrete in Europe. Constr. Build. Mater. 2021, 307, 124946. [CrossRef]

2. Xiao, J.; Long, X.; Qu, W.; Li, L.; Jiang, H.; Zhong, Z. Influence of sulfuric acid corrosion on concrete stress-strain relationship under uniaxial compression. Measurement 2022, 187, 110318. [CrossRef]

3. Boğa, A.R.; Topçu, İ.B. Influence of fly ash on corrosion resistance and chloride ion permeability of concrete. Constr. Build. Mater. 2012, 31, 258-264. [CrossRef]

4. Ai, Z.; Sun, W.; Jiang, J.; Song, D.; Ma, H.; Zhang, J.; Wang, D. Passivation characteristics of alloy corrosion-resistant steel Cr10Mo1 in simulating concrete pore solutions: Combination effects of $\mathrm{pH}$ and chloride. Materials 2016, 9, 749. [CrossRef] [PubMed]

5. Jamali, A.; Angst, U.; Adey, B.; Elsener, B. Modeling of corrosion-induced concrete cover cracking: A critical analysis. Constr. Build. Mater. 2013, 42, 225-237. [CrossRef]

6. Yalciner, H.; Eren, O.; Sensoy, S. An experimental study on the bond strength between reinforcement bars and concrete as a function of concrete cover, strength and corrosion level. Cem. Concr. Res. 2012, 42, 643-655. [CrossRef]

7. Brooks, E.K.; Brooks, R.P.; Ehrensberger, M.T. Effects of simulated inflammation on the corrosion of 316L stainless steel. Mater. Sci. Eng. C 2017, 71, 200-205. [CrossRef] [PubMed]

8. Loable, C.; Viçosa, I.N.; Mesquita, T.J.; Mantel, M.; Nogueira, R.P.; Berthomé, G.; Chauveau, E.; Roche, V. Synergy between molybdenum and nitrogen on the pitting corrosion and passive film resistance of austenitic stainless steels as a pH-dependent effect. Mater. Chem. Phys. 2017, 186, 237-245. [CrossRef]

9. Shi, X.; Xie, N.; Fortune, K.; Gong, J. Durability of steel reinforced concrete in chloride environments: An overview. Constr. Build. Mater. 2012, 30, 125-138. [CrossRef]

10. Yu, Z.; Ye, G. The pore structure of cement paste blended with fly ash. Constr. Build. Mater. 2013, 45, 30-35. [CrossRef]

11. Zeng, Q.; Li, K.; Fen-chong, T.; Dangla, P. Determination of cement hydration and pozzolanic reaction extents for fly-as cement pastes. Constr. Build. Mater. 2012, 27, 560-569. [CrossRef]

12. Tsouli, S.; Lekatou, A.G.; Siozos, E.; Kleftakis, S. Accelerated corrosion performance of AISI 316L stainless steel concrete reinforcement used in restoration works of ancient monuments. MATEC Web Conf. 2018, 03003, 1-8. [CrossRef]

13. Tsouli, S.; Lekatou, A.G.; Kleftakis, S. The effect of fly ash on the corrosion performance of AISI 316L stainless steel reinforced concrete for application to restoration works of ancient monuments. In Proceedings of the 10th International Symposium on the Conservation of Monuments in the Mediterranean Basin, Athens, Greece, 20-22 September 2017; pp. 171-178. [CrossRef]

14. Tsouli, S.; Lekatou, A.G.; Nikolaidis, C.; Kleftakis, S. Corrosion and tensile behavior of 316L stainless steel concrete reinforcement in harsh environments containing a corrosion inhibitor. Procedia Struct. Int. 2019, 17, 268-275. [CrossRef]

15. Tsouli, S.; Lekatou, A.G.; Kleftakis, S.; Matikas, T.E.; Dalla, P.T. Corrosion behavior of 304L stainless steel concrete reinforcement in acid rain using fly ash as corrosion inhibitor. Procedia Struct. Int. 2018, 10, 41-48. [CrossRef]

16. Lekatou, A.G.; Tsouli, S.; Nikolaidis, C.; Kleftakis, S.; Tragazikis, I.K.; Matikas, T.E. Effect of fly ash on the corrosion performance and structural integrity of stainless steel concrete rebars in acid rain and saline environments. Frat. Integrita Strutt. 2019, 13, 423-437. [CrossRef] 
17. Matikas, T.E.; Karpur, P.; Shamasundar, S. Measurement of the dynamic elastic moduli of porous titanium aluminide compacts. J. Mater. Sci. 1997, 32, 1099-1103. [CrossRef]

18. Sinsiri, T.; Chindaprasirt, P.; Jaturapitakkul, C. Influence of fly ash fineness and shape on the porosity and permeability of blended cement pastes. Int. J. Min. Met. Mater. 2010, 17, 683-690. [CrossRef]

19. Wang, Q.; Feng, J.; Yan, P. The microstructure of 4-year-old hardened cement-fly ash paste. Constr. Build. Mater. 2012, 29, 114-119. [CrossRef]

20. Papadakis, V.G. Effect of fly ash on Portland cement systems: Part II. High-calcium fly ash. Cem. Concr. Res. 2000, 30, 1647-1654. [CrossRef] 